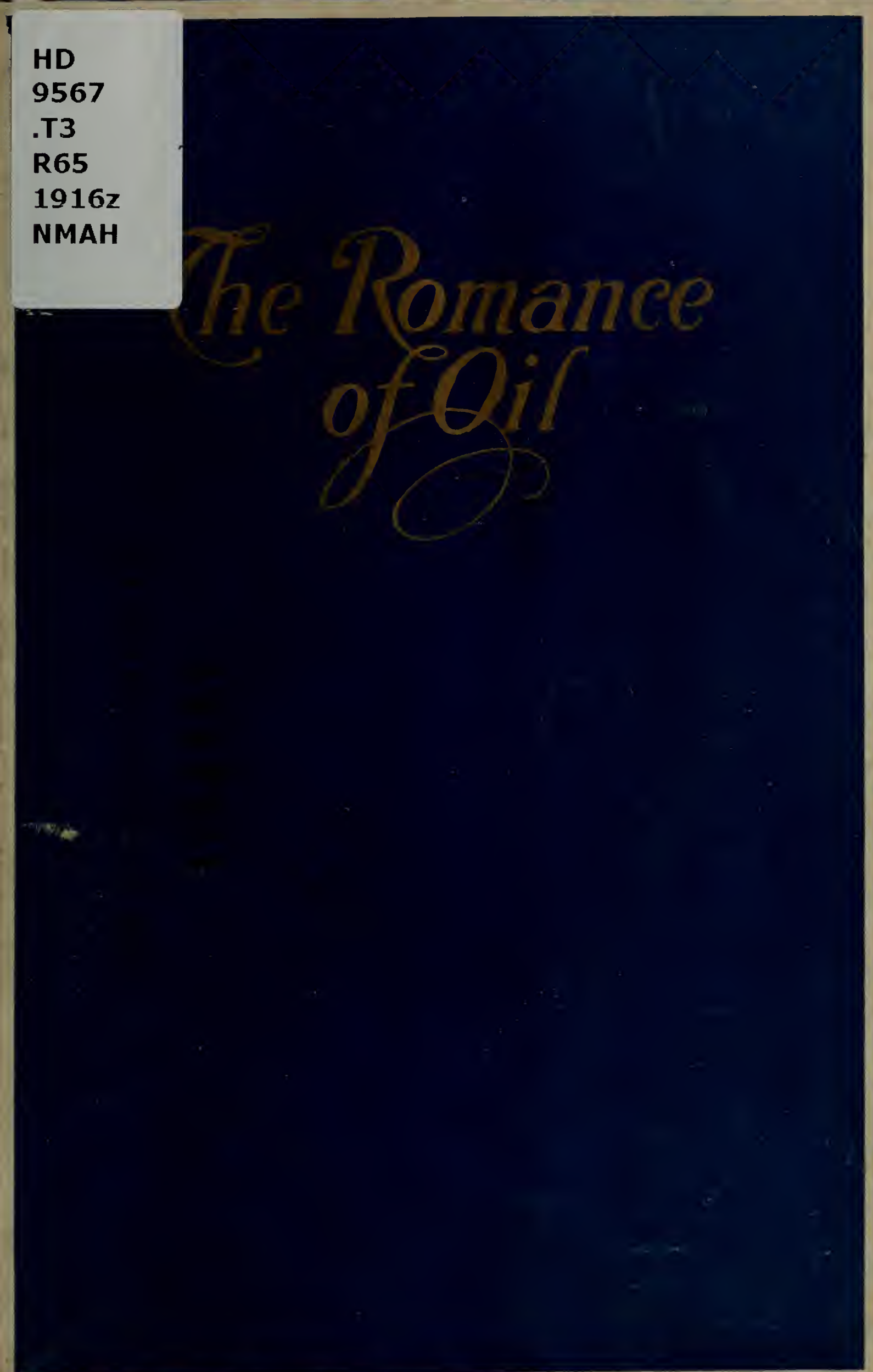







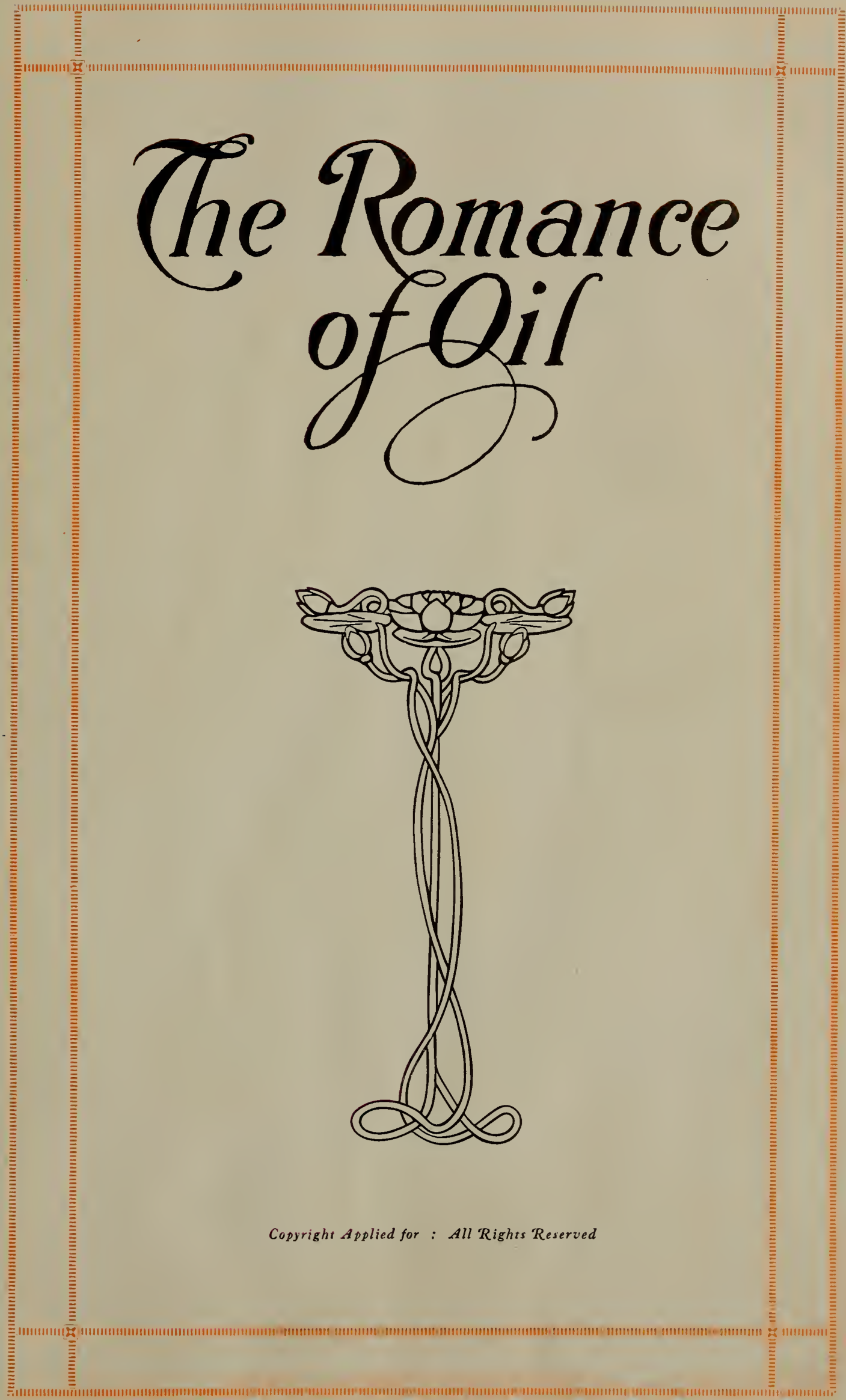




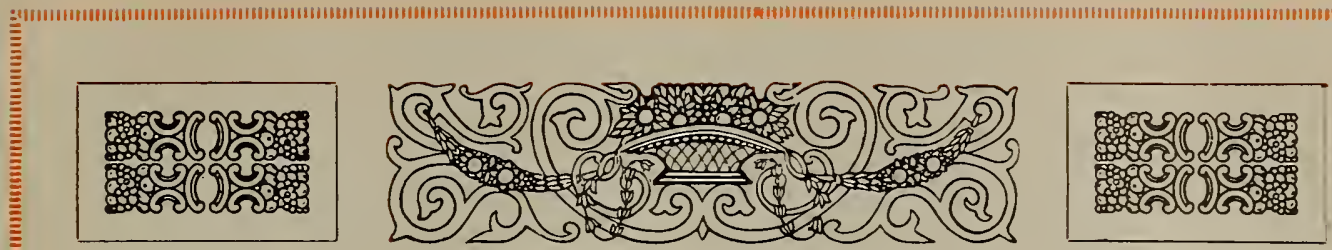

\section{THE ROMANCE OF OIL}

(8)

\section{A DREAMER OF DREAMS.}

The dreamer of dreams is the maker of fortunes. Without the man who sees the vision, great projects would never come to fruition nor great things be accomplished.

About the year 1900 a man in Beaumont, Texas, had a dreama day dream that later came true. This man was Patillo Higgins, father of the coastal oil fields. Mr. Higgins dreamed that the district to the south of Beaumont, a short distance, would one day become a great oil field. His dream came true in spite of the fact that learned geologists in the employ of the State warned the people of Beaumont that Patillo Higgins' dream would never be a reality, but was simply the wish fathering the thought.

However, Mr. Higgins, being thoroughly grounded in his belief that a big oil field existed at Spindle Top, kept on and on until he not only secured funds for drilling, but through his activities induced others to put down wells, among them Captain Lucas, who put his last dollar into the ground and one day was rewarded by a roar and a big gush of oil, bringing in the Lucas gusher, the first well on Spindle Top, reported to have made an initial production of 70,000 barrels of oil per day.

This was the beginning of the development of the wonderful coastal oil fields, and the cause of a great rush to Spindle Top, where gushers were brought in that are said to have made as high as 200,000 barrels daily. Every one who had money in small or large amounts went into the oil business, and Patillo Higgins' dream became a reality. Thousands from every part of the United States flocked to Beaumont, money "flowed like water," crowds jostled in the streets, lands anywhere in the vicinity of Spindle Top became worth a fortune over night, oil companies were organized, millions were invested, fortunes were made or lost, and men were wild. One man bought a thirty-second of an acre and brought in a gusher making 25,000 barrels a day.

\section{DREAMS GROW APACE.}

After the discovery of the Spindle Top field there began to be what is known in oil parlance as "wild-catting," in the hope of discovering other oil fields, with the result that Sour Lake, Saratoga and Batson were developed, then the great Humble field, where so many fortunes were made in gusher wells. Later, Goose Creek developed into an oil field of small proportions with practically nothing but little wells known as "pumpers." But in the fall of 


\section{THE ROMANCE OF OIL}

1916, Goose Creek suddenly came into the limelight as one of the big gusher fields, when the deep sand stratum was discovered and the big American well came in with an estimated initial production of 20,000 barrels daily. It had been predicted by many oil men that Goose Creek would be one of the big gusher fields.

Beginning with Spindle Top, several great fields have been developed in the coastal belt during the past fifteen years, and yet it has been openly stated by some of the most successful oil operators in this section that the Coast Country has only been "scratched" so far as oil development is concerned. These men predict that many more fields will be opened and, like the dream of Patillo Higgins, their predictions may become a reality and mean scores of additional fortunes from rich deposits of oil in Mother Eartl.

The overwhelming demand for petroleum and its products is the stimulus behind the present unprecedented activity in the development of oil properties. Gasoline, that by-product of petroleum, which a few years ago was allowed to go to waste, is today one of the most valuable products of refineries. Most of us can remember when gasoline was considered as dangerous a substance as nitroglycerine, and which every one was anxious to keep at a safc distance. Today it is in as common use as kerosene once was. In fact, it is estimated that the consumption of gasoline during 1917 will reach the astounding total of ONE BILLION, FIVE HUNDRED MILLION GALLONS, or more than fifteen gallons for every man, woman and child in the United States.

And yet, gasoline is only one of the many by-products of petroleum. Kerosene, lubricating oil, paraffine, asphaltum and fuel oil are products with which nearly every one is now familiar.

Never in the history of the world has the demand for petroleum been so great as at the present time; and never before in the history of oil has the production been so great as now. In 1859, according to government tables, oil developments in the entire country resulted in a production of only 2,000 barrels Statistics for the year 1916 are not yet available, but the production for 1915 in the United States alone amounted to nearly $300,000,000$ barrels.

The demand for petroleum and its by-products will probably never be met. The multiplying uses to which it has been found this substance can be put are creating a demand that far out-runs every prospective source of supply; and a prominent oil man predicts that petroleum will sometime bring the amazing price of ten dollars a barrel at the well.

\section{ANOTHER DREAM COMES TRUE.}

Shortly after Mr. Higgins predicted that these great oil fields would be discovered at Spinlde Top, another man had a dreama man with years of experience in the oil business and a man who knew about the wonderful profits made in the operation of this business. This man is J. S. Cullinan, who had come to Texas from Pennsylvania in the employ of one of the large oil companies. Mr. Cullinan evidently had a vision of the possibilities of oil production, for he 


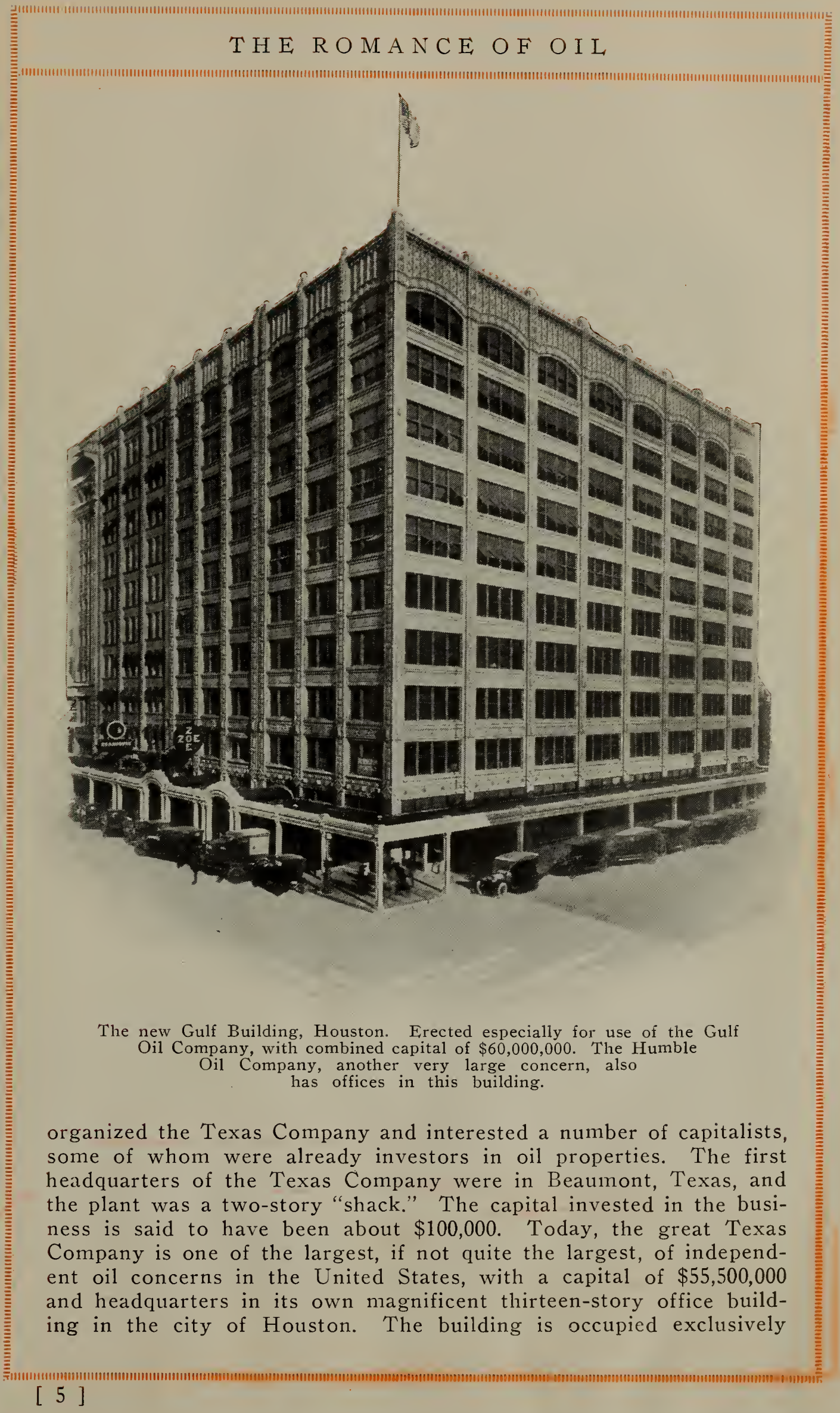


THE ROMANCE OF OIL

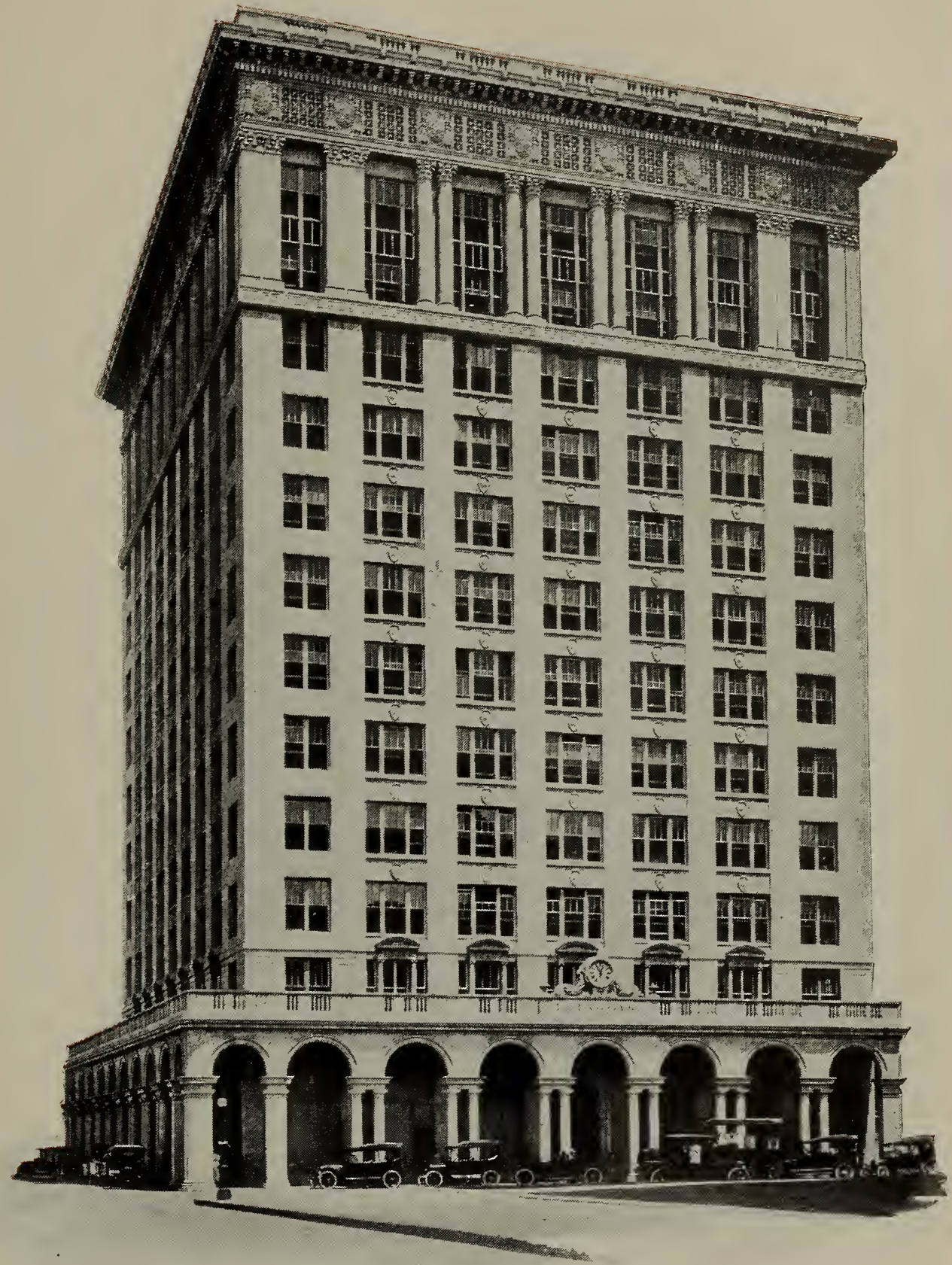

The magnificent office building owned and occupied by the Texas Company, situated at the corner of Rusk and San Jacinto Streets, Houston. This is the finest office building in the world occupied exclusively by an oil company. The capital of the Texas Company is now $\$ 55,500,000$. 


\section{THE ROM A N C E O F O I L}

is situated, when many operators predicted that the best of the field was worked out and the territory practically drained. This prediction, however, proved to be erroneous, for Humble came back stronger than ever.

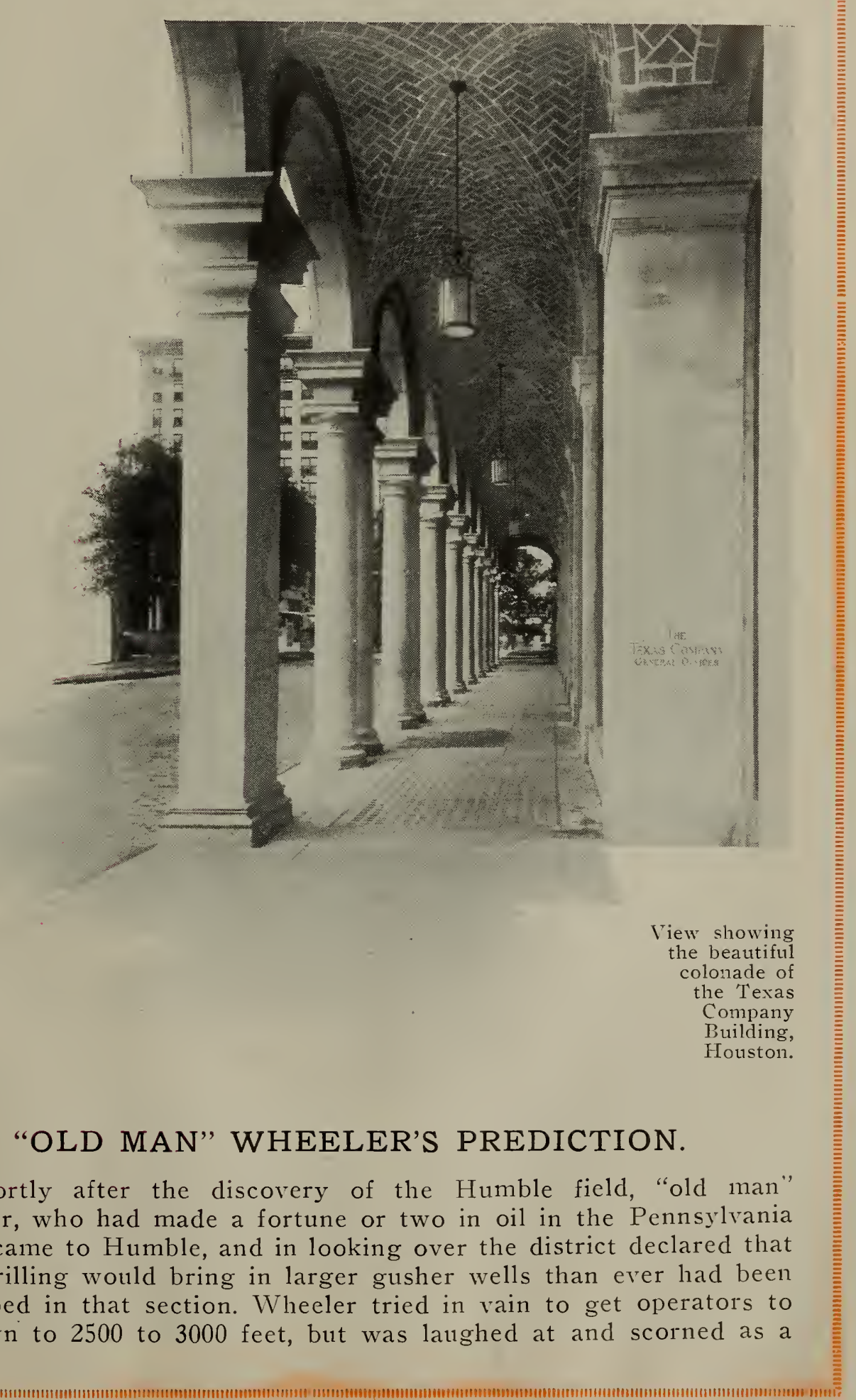




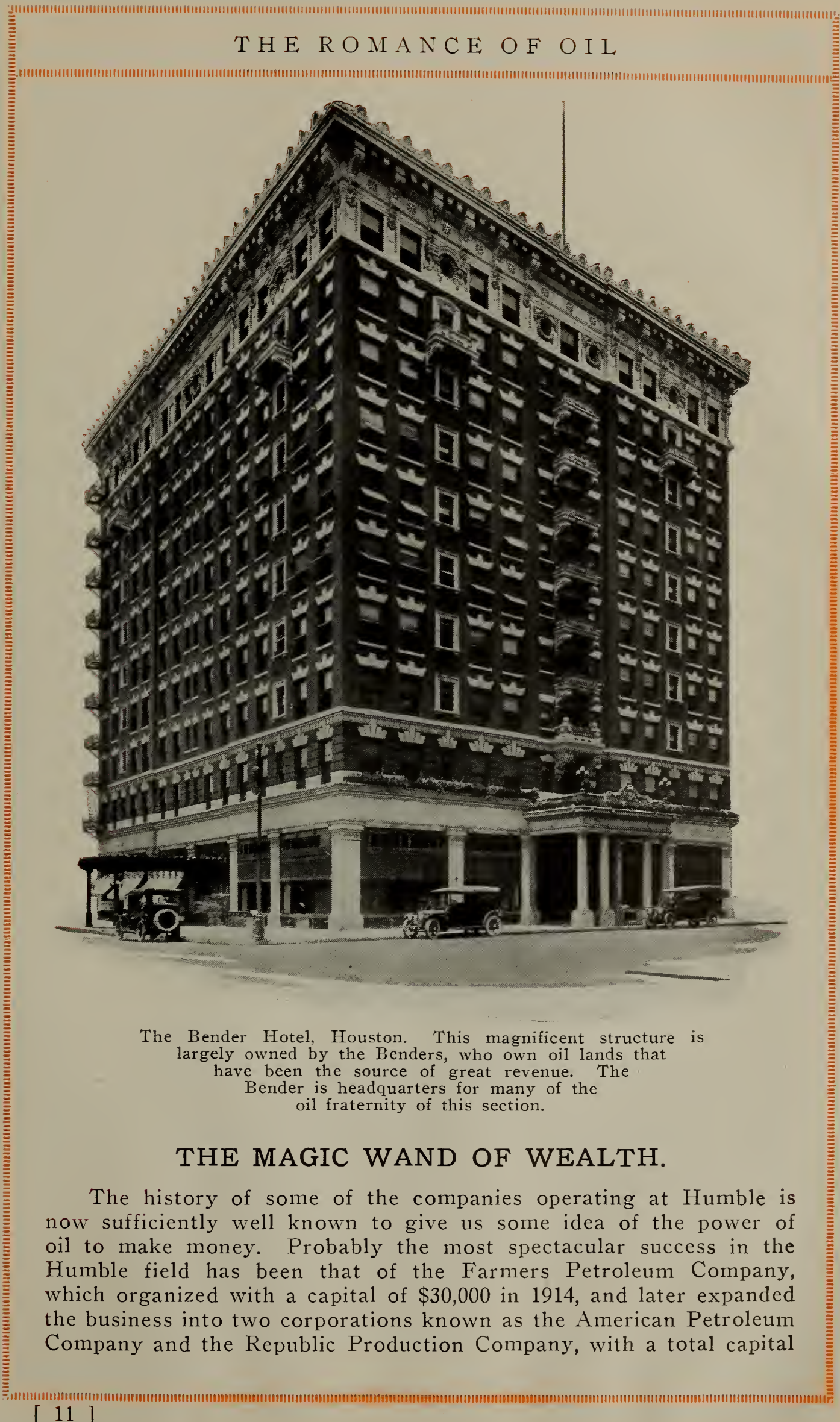

[ 11 ] 
of $\$ 3,000,000$, or exactly one hundred times the original capital of the Farmers Company, and with assets estimated at about $\$ 8,000,000$. This growth was made in a period of two years, and the profits which enabled the company to make such wonderful progress were practically all made, if not quite, from wells on the Stevenson land at Humble, where "old man" Wheeler claimed there was a big pool of oil during the early days.

\section{A FIFTY-MILLION-DOLLAR “MUD HOLE.”}

Shortly after Spindle Top was discovered, it was rumored that the Sour Lake district had splendid indications of oil. In fact, it later became a certainty that surface indications were even better than at Spindle Top. A few venturesome prospectors went to Sour Lakc and announced their intention of drilling, with the result that the big companies-among which was the Texas Company-bcgan negotiations for leases.

Sour Lake was an inland town. The water being of a mineral nature in that district had given the place some fame as a health resort, but most people called it a "mud hole." After a time wells were started, and soon gushers were brought in making Sour Lake what was sometimes called a "fifty-million-dollar mud hole." Up to the present time Sour Lake has continued to produce a considerable quantity of oil and has proven to be a far better field than Spindle Top. However, it is probable that Sour Lake will produce more oil in futurc than it has in the past, because new gusher territory has recently been opened up by deep drilling-just as it was at Humble in 1914.

The Texas Company made a great deal of money in the Sour Lake field by gaining control of some nine hundred acres in a very productive part of the field, before the property was all taken. The wisdom of this policy-that is getting every acre possible under control in a prospective field-was demonstrated in this very instance by the Texas Company. Any company that secures control of so large a property in a new field, especially in gusher territory, is practically certain to make millions.

\section{HOW OIL SAVED THE DAY FOR TRAVELING MEN.}

How a failing health resort property was turned into a million dollars cash is a story often told by old-time traveling men of South Texas. Some time before oil was thought of at Sour Lake a number of traveling men conceived the idea of establishing a health resort at that point because of the mineral waters, hot springs, hot wells and the curative properties of these waters, demonstrated by the fact that people came hundreds of miles in many instances to Sour Lake for treatment. In fact some thought these waters would cure anything.

So traveling men organized a company of $\$ 100,000$ and took 


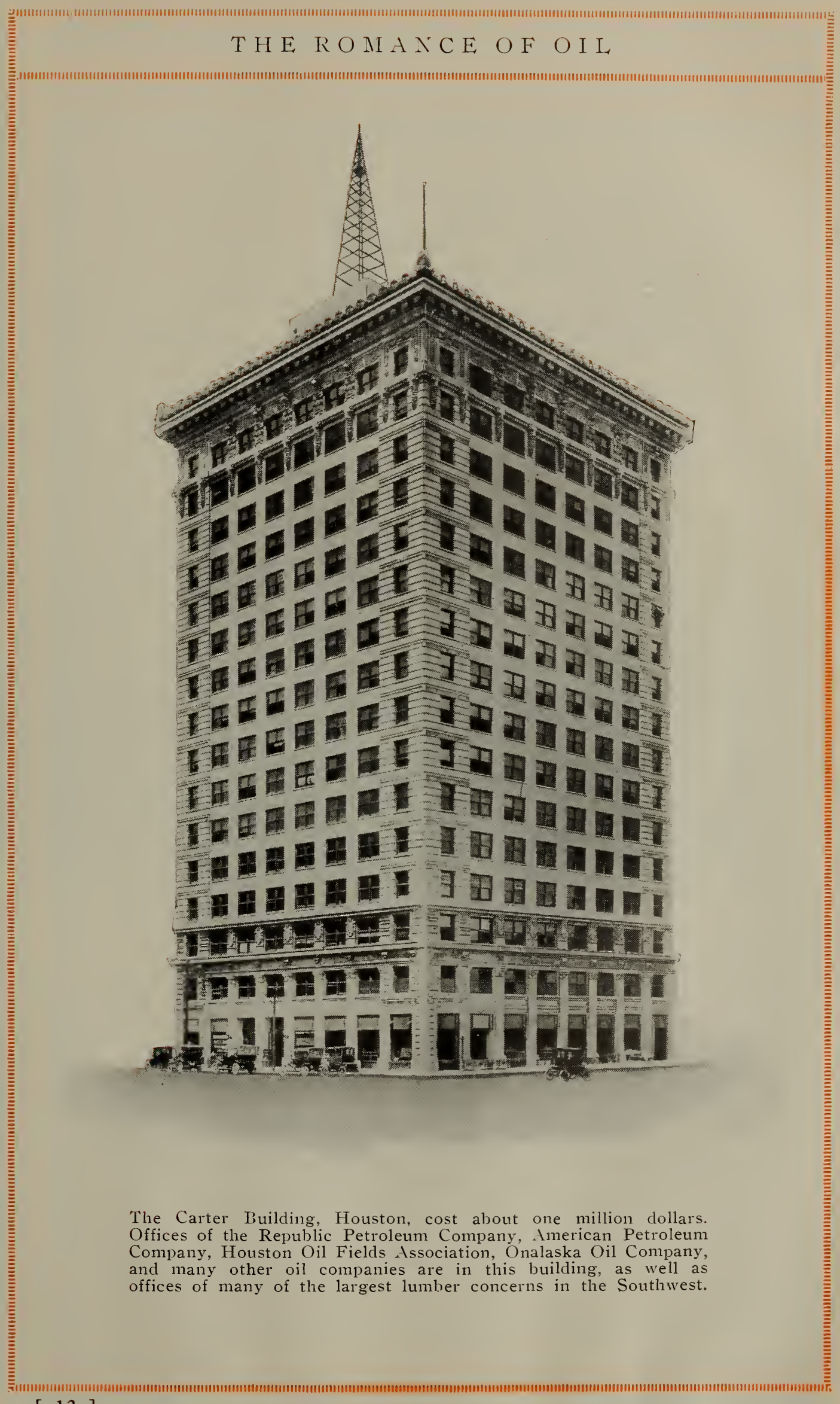




\section{THE ROM A N CE OF O I L}

over 800 acres of land, including the hotel, which is now the heart of the Sour Lake oil field.

The financial affairs of this company, however, did not come out just as the stockholders anticipated. There were many obstacles to overcome. Sour Lake was an inland town, difficult to reach, and not a very inviting place those days after the visitor finally arrived. The country was sparsely settled, few patients came, at least not a sufficient number to make the resort business profitable. Stock in the company became almost worthless, could have been had for five cents on the dollar. The officers of the company were in despair. They did not have much hope of ever pulling the company "out of the hole."

About the time the clouds became darkest, however, rumors began to be circulated that Sour Lake was thought to be an oil field. Scouts for some of the oil companies began to arrive and look

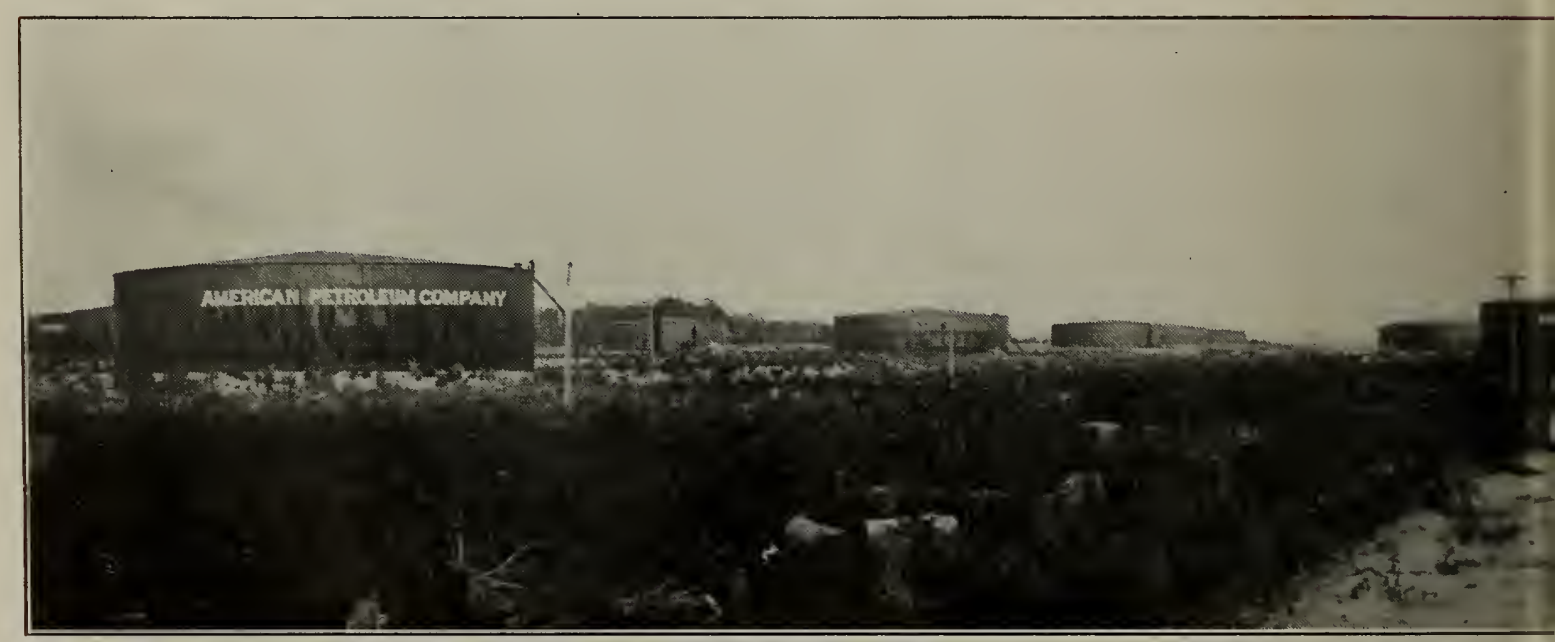

Great "Tank Farm" of the American Petroleum Company at East Houston. When this photograph was made there was

the situation over. The resort company was in a tight place, and the oil companies thought perhaps a little more time would even put the company into receivership and the property could then be purchased for little or nothing. But some of the more shrewd among the stockholders decided they would hang on, and when a weakkneed stockholder would become too anxious to sell out, the stouthearted ones would buy his shares. This went on for months.

Finally, when it seemed that there was little use to hang on longer, the Texas Company-which was then a comparatively small concern-offered the resort people a cool million dollars for the 800 acres of land. The offer was accepted, and the first dividend the resort company paid on its stock was 850 per cent, and the stock could have been had for five cents on the dollar a short time before. In all, the shareholders in the resort company received ten dollars for each dollar par thcir stock represented.

It is said the late John IV. Gates, the multi-millionaire who 

over 800 acres of land, including the hotel, which is now the heart of the Sour Lakc oil field.

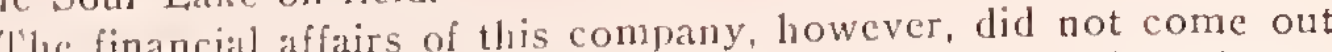
Just as the stockbore many obstacles to

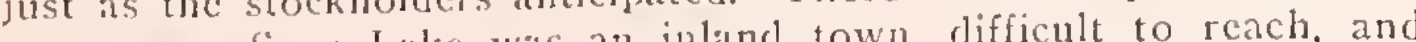
overeome. Sons Lake was an inland town, dificer finally arrived. not a very inviting place those lays antor the visitor finally arrived. The country was sparsely setted, few paticnts came, a least not a sufficicut number to make the resort business profitable. Stock in the company became almost worthless, could have becn had for five cents on the dolar. The officers of the company were jin despair. They lis not have mucl boue of ever pulling the company "out of the hole."

About the time the clouds became darkest, however, rumors began to be circulated that Sour I Iake was thought to be an oil ficld. Scouts for some of the oil companies began to arrive and look showed such great faith in Texas oil investments, and who made for himself and his estate so many millions on these imvestments, fur nished the million dollars the Texas Company paid for the Sour Lake property.

In any event, it was a good investment for the Texas Company, as it is estimated that some $\$ 15,000,000$ worth of oil has already been taken from the land. It was certainly a good sale for the stockholders in the resort company, as it gave them a profit of 900 per cent above par on their stock. Oil saved the day in this case, as it has in scores of other instances.

\section{A RIVAL OF ROCKEFELLER.}

After the recent presidential election, the newspapers carried a story that E. L. Doheny won a half-million dollars on election bets.

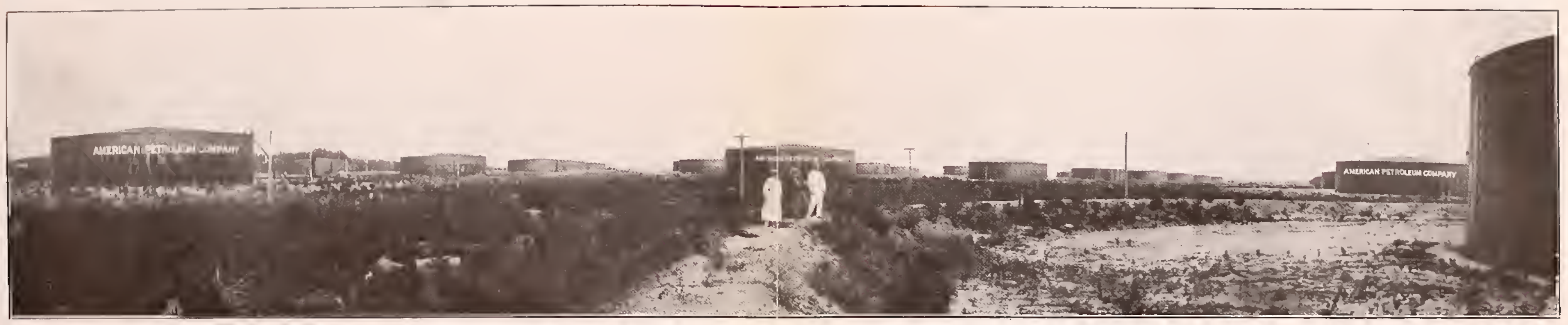

Great "link Farm" of the American Petroleum Company at East Houston. These tanks have a capacity of 55,000 barrels of oil, and there are about sixty of them.
When this plotograph was made there was reported to be over two milion barrels in storage.

the siturtion orwe. The resort company was in a tight place, and the oil companies thought perhaps a litte more time would even put the company into receivership and the property could then be purchased for little or nothing. But some of the more shrewd among the stockloklers decided they would hang on, and when a weakkneed stockholder would become too anxious to sell out, the stoutlicarted oues would buy his shares. This went on for months.

linally, when it secmed that there was little use to hang on longer, the lexas Company-which was then a comparatively small concern-offered the resort people a cool million dollars for the 800 acres of land. The offer was accepted, and the first dividend the resort company paid on its stock was 850 per cent, and the stock could have becu had for five cents on the dollar a short time before. In all, the sharcholders in the resort company received ten dollars for catch dollar par their stock represented.

It is said the late Joln WV. Gattes, the multi-millionaire who
This story brings to mind the fact that Doheny is sometimes called the "King of Wild-catters," and is probably the only man in this country who approaches Rockefeller in the scope of his operations. How Mr. Doheny happened to get into the oil business and become the head of the great Pan-Amcrican Petroleum \& Transport Company, with a capital of $\$ 150,000,000$, is another "romance of oil."

It is told that Doheny was one day walking through a park in Los Angeles wlien the city was having the strects graded and the graders had made quite a cut. Mr. Doheny noticed this cut and found secping from the earth a substance with the appcarance of oil. He immediatcly set about to get a mineral lease on this bit of park land, and after accomplishing this, began to dig with pick and shovel. He tunneled in the direction from which the seepage came, and after going some two hundred feet, came to a flowing stream of oil. It is said that Doheny, having no market for this oil, went to a laundry, convinced the owner that he conld cut down his fucl bill, procecded 


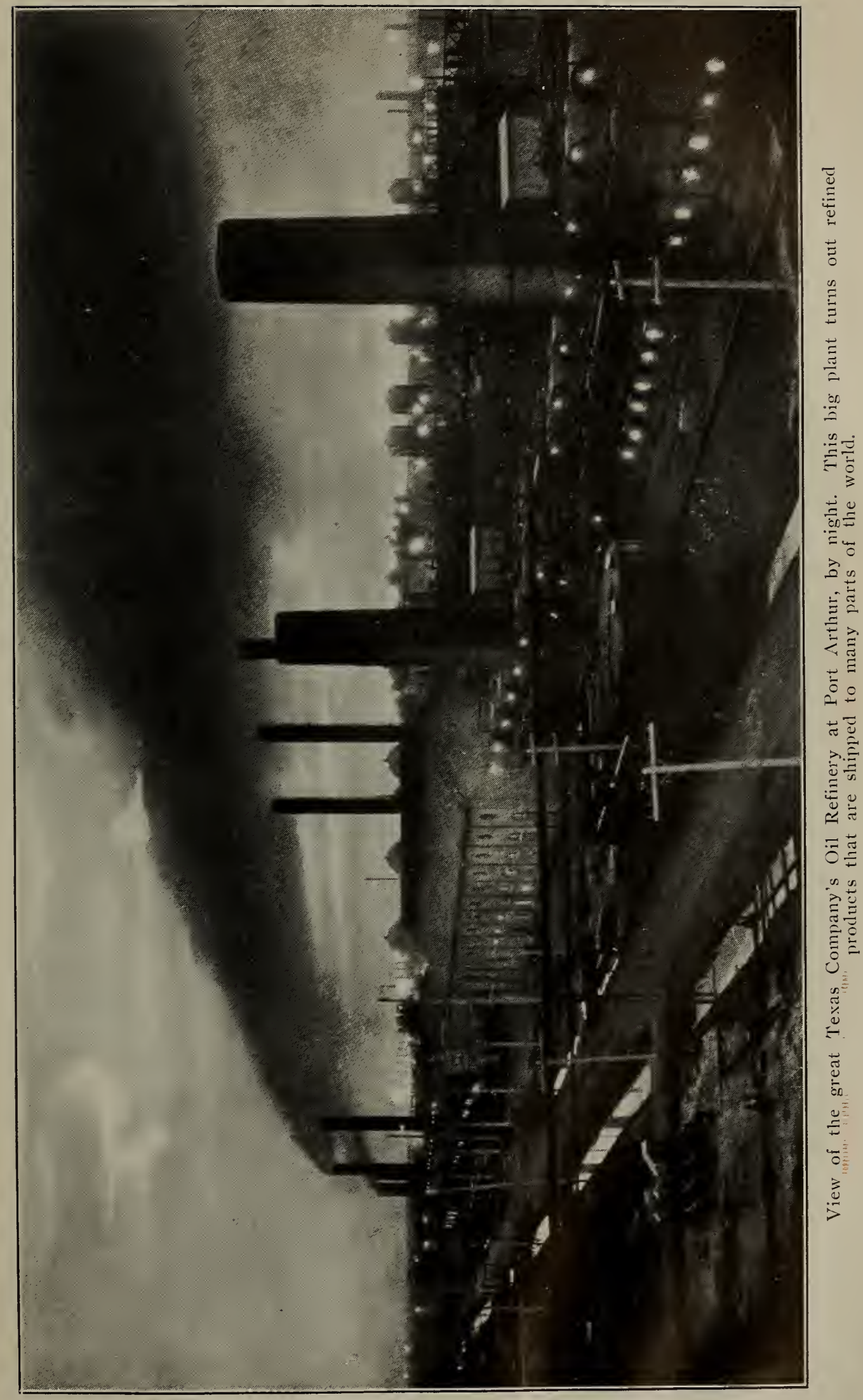


but those who were sufficiently wise to hold on, netted very handsome returns indeed. Onc dollar invested and $\$ 30$ back in twelve months' time-isn't that what you call a paying investment?

The Producers Oil Company of Houston paid a six million dollar dividend-200 per cent on the capital stock of the company-during its last fiscal year, and a great part of these millions was made from the gusher wells of the Producers Company at Humble. The Deep Sand Oil Company made a big strike which made large profits for its stockholders during 1915 in the Humble gusher field. The organizers of this company were not experienced in the oil business to any considerable extent, but were good business men and used proper judgment in the management of the company's operations.

\section{COURAGE IS REWARDED.}

One of the most striking examples of large returns to small investors was the operations of the Hoffman Oil Company, which was organized about July, 1915 , and had a capital of $\$ 12,000$. The organizers were men of no experience in the oil business, but secured competent drillers, brought in good wells in the shallow district at Humble, and in March of the following year-only about nine months-the company sold out to the Gulf Coast Oil Corporation at a price which netted the stockholders about twenty-nine dollars for every dollar invested at the original purchase price of the stock. The new corporation was capitalized at $\$ 500,000$, and is today one of the strong oil concerns of this section.

Neils Esperson, who landed in Galveston a few years ago, after having followed the sea for a livlihood many years, began in the Humble field with very little capital and drilled a dozen wells before he struck a big one, interesting others in the venture from time to time in order to continue operations. A short time ago, however, he was able to buy properties at Humble for a consideration of more than one million dollars. In fact, it is said that one well drilled by Esperson in this field produced over a million dollars' worth of oil, and that Esperson made over a million dollars for Eastern parties, who virtually "grub staked" him for his early operations.

\section{FORTUNE SMILES-AND POOR MEN BECOME WEALTHY.}

Two Houston men who were both interested in oil met one day not long ago and were discussing the business, when one asked the other whether he thought there was a chance for the "little man" in oil investments or operations. After giving the question a moment's thought, the second man answered that he thought there certainly was a better opportunity than in almost any business he knew of.

"Why," he said to his friend, "didn't Dave Beatty borrow money to go into the oil business at Spindle Top, and isn't he one of our wealthiest citizens today?"

"Yes, that is what they say," replied the first. 


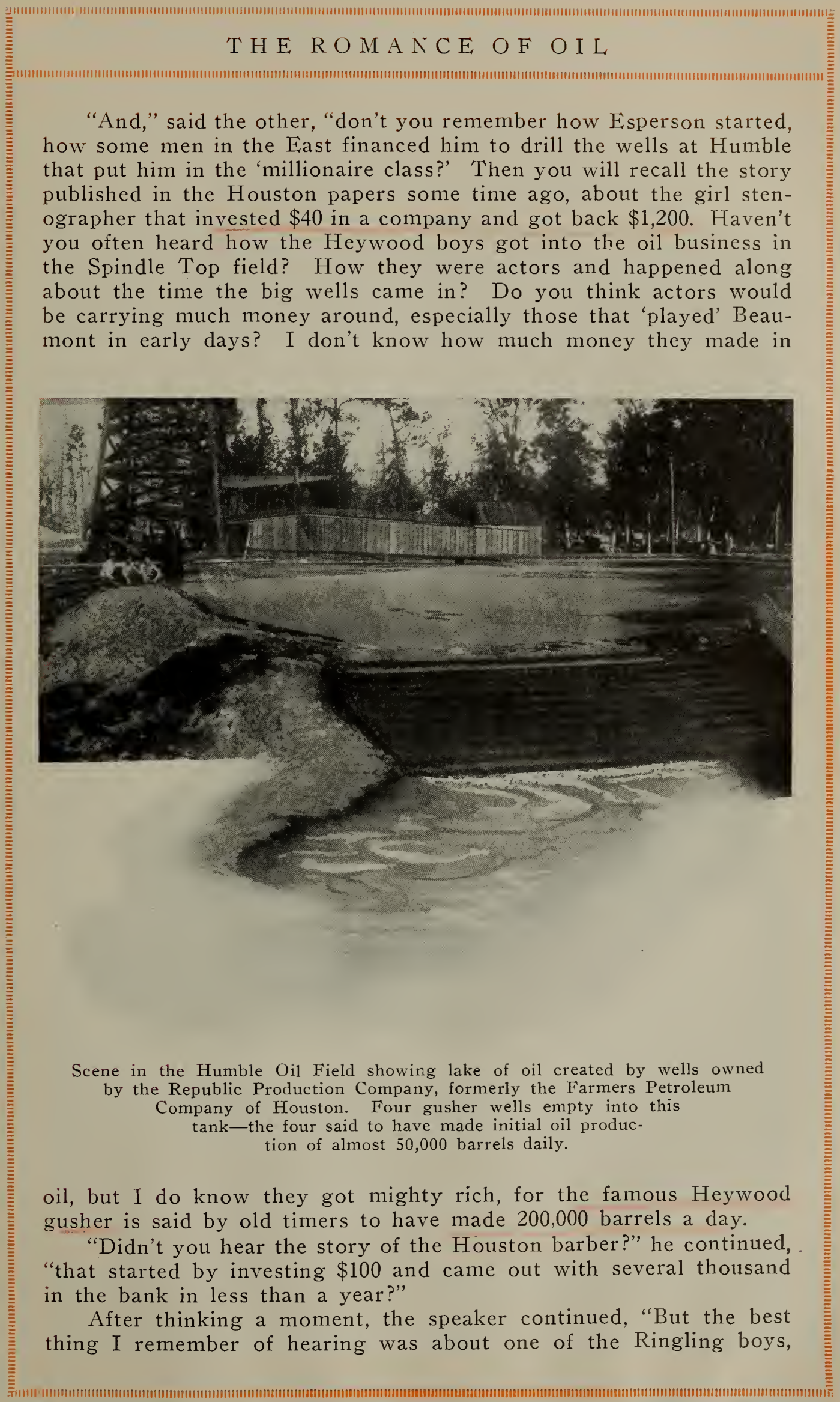




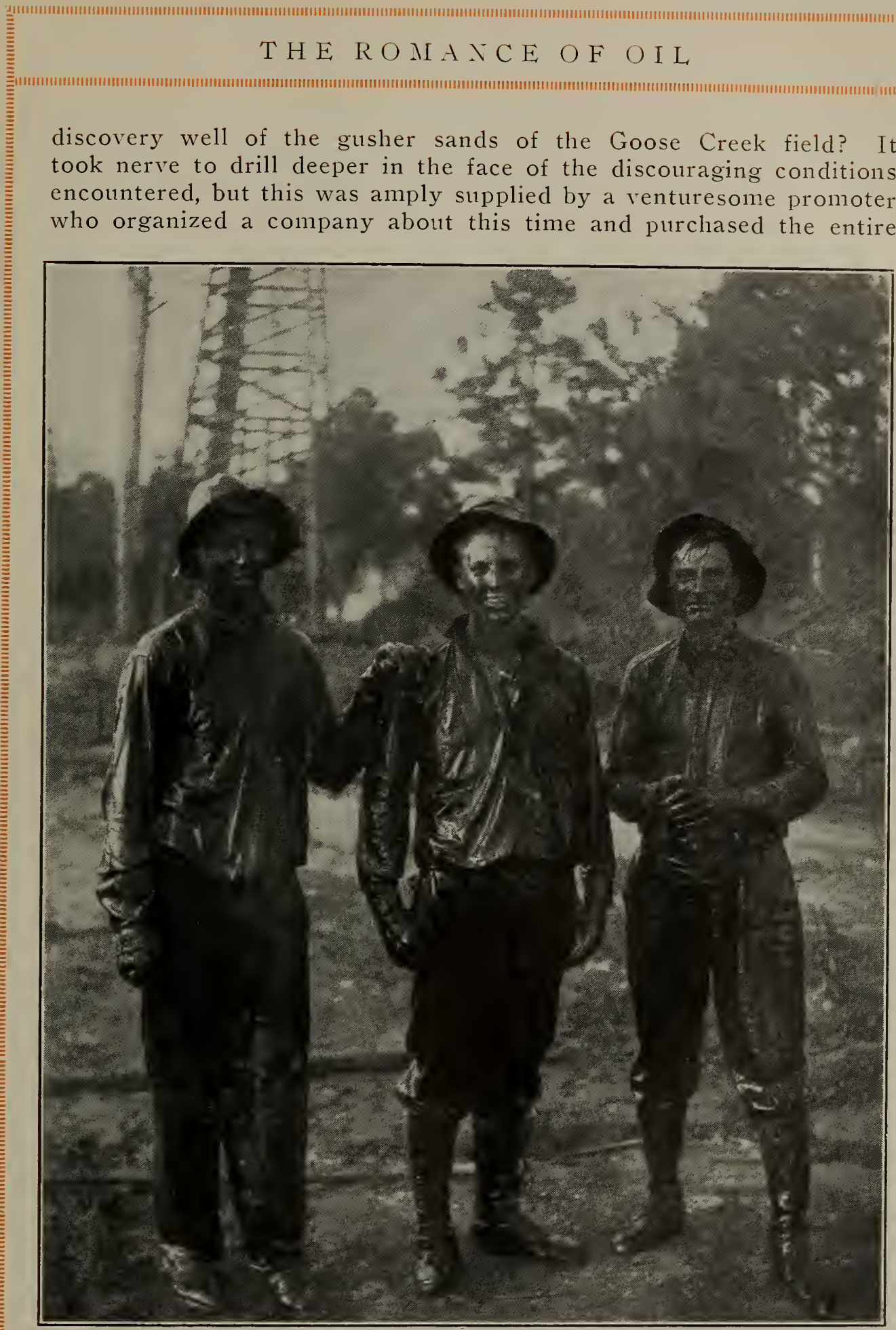

Typical oil field workers, just after a gusher well came in. They are covered with oil, but quite cheerful about it, for another big strike has been made.

holdings of these disappointed owners. The new owners began immediately to drill deeper, and when something over two thousand feet was reached, a great roar and rumble and gush of oil heralded the bringing in of a mighty gusher with a reported initial flow of

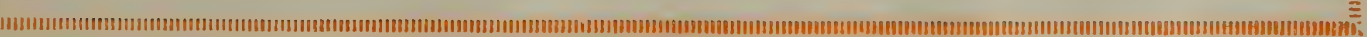


20,000 barrels of oil daily. Thus the first owners lost a fortune, and the new ones reaped a "bumper" harvest of profits. Incidentally, too, a new day dawned for Goose Creek with the bringing in of this well-a day of scramble and excitement and new developments that soon put this hitherto neglected district in the forefront of coastal oil fields.

Veteran oil operators from all parts of the country rushed to the field. Land that was called practically worthless became of great value. Leases that could have been had for the asking at modest royalties brought thousands of dollars an acre in bonuses, with larger royalties than usual.

\section{GOOSE CREEK “NEW HOPE” OF OIL MEN.}

Always the operator is looking for new worlds to conquer. Sometimes an operator will take long chances if possible profits are sufficient to warrant. An instance of this kind in connection with Goose Creek field is the case of C. T. Rucker who is said to have invested practically every dollar he had in Goose Creek before the big gushers came in, on his judgment that it would be a great field some day. The tide turned for Rucker, he made a fortune worth a lifetime of effort, and is on easy street today. The discovery of the deep gusher sands at Humble spurred oil operators on to greater efforts to find a new gusher field. Goose Creek had produced but a small amount of oil until the fall of 1916, still Rucker and other operators hung on and spent hundreds of thousands of dollars endeavoring to make Goose Creek properties pay.

When the first big gusher in this field came in, Goose Creek became the "new hope" of the oil fraternity of the Southwest, because the territory was practically open, and therefore offered an opportunity for a "free-for-all" scramble for leases. It is predicted by some that Goose Creek will equal, if not exceed Humble in gusher production. Rigs are running day and night, hundreds of carloads of materials have been put on the ground, every available acre leased, and in fact the territory for miles out is now largely under control of oil companies and operators. Men who owned land adjacent to Goose Creek who would have gladly sold it for $\$ 50$ an acre, today ask from $\$ 100$ to $\$ 10,000$ per acre bonus for the privilege of drilling wells, and expect full royalties from any oil produced, in addition. A Houston man paid $\$ 1200$ bonus for a lease at Goose Creek and resold the lease rights the next day for $\$ 12,000$. It is reported that another man made $\$ 40,000$ net profit simply by the transfer of a lease. He did not drill a well nor put a dollar into developing the property. One lease was sold recently for $\$ 15,000$ an acre in addition to the owners' share of the oil. One company started actual operations in the Goose Creek field about six months ago with a capital of $\$ 100,000$, and is now capitalized at a half-million dollars, owns leases valued at hundreds of thousands of dollars, to say nothing of the value of the wells on the property. Another company has made a very handsome profit on its capital just through sub-leasing to others from the bonuses and interests in wells which it acquired in this way, and has only 


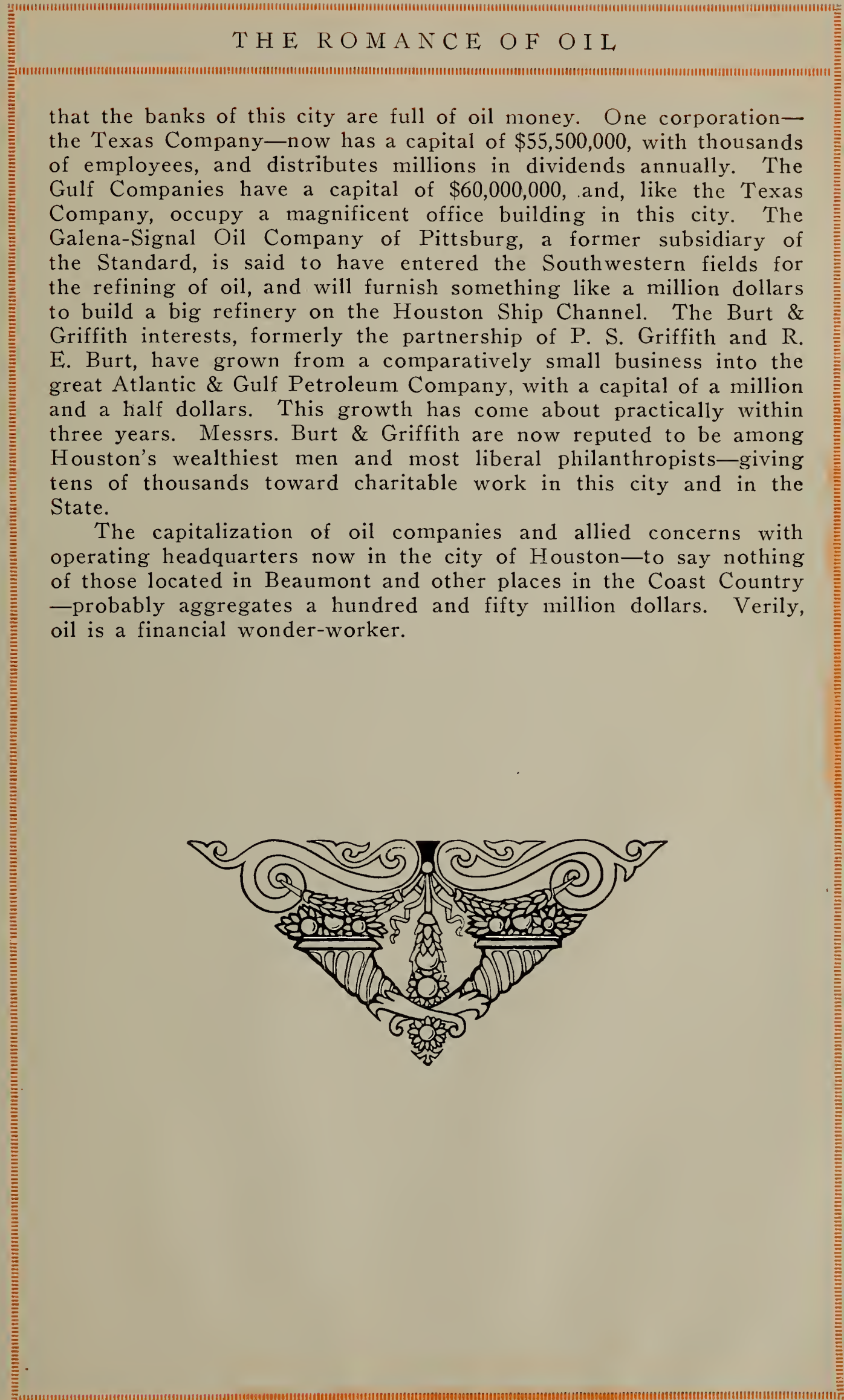


SOUTHWESTERN PRESS, PRINTERS HOUSTON, TEXAS 



SMTTHSONIAN INSTITUTION LIBRARIES

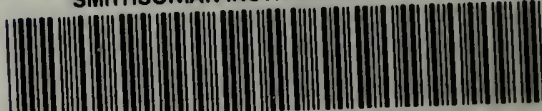

39088015402829 